\title{
Linking Corporate Risk Disclosure Practices with Firm-Specific Characteristics in Saudi Arabia
}

\author{
Omer Saeed Habtoor, ${ }^{1}$ Norsiah Ahmad, ${ }^{*}$ Nor Raihan Mohamad, ${ }^{3}$ and Mohd Hassan Che Haat ${ }^{3}$ \\ ${ }^{1}$ Community College, Northern Border University Kingdom of Saudi Arabia \\ ${ }^{2}$ Faculty of Economics and Management Sciences, Universiti Sultan Zainal Abidin, Kuala Terengganu, Malaysia \\ ${ }^{3}$ School of Maritime Business and Management, Universiti Malaysia Terengganu, Kuala Terengganu, Malaysia
}

\begin{abstract}
This study explores Corporate Risk Disclosure practices (CRD) in the annual reports of Saudi (non-financial) listed companies and investigates the relationship between the Saudi firm-specific characteristics and the level of such practices. Using content analysis of a sample of 307 company-year observations over the period of 2008-2011, the results indicate that Saudi Arabia provides a moderate level of CRD among the developed and developing countries. However, the content of this CRD is found to be of a low quality, by including non-financial, qualitative, neutral, or non-time-specific information. In addition, the unbalanced panel regression analysis shows a significant positive influence of firm size and audit firm size on the level of CRD. This indicates that Saudi companies which disclose higher risk-related information are those characterised by their larger size, and are audited by the Big 4 audit firms. This study contributes to the risk literature by providing an initial understanding of the CRD practices and their variations in light of the firm-specific characteristics in emerging markets in general and Arab countries in particular..
\end{abstract}

Keywords: annual reports; corporate risk disclosure; firm-specific characteristics; Saudi Arabia

JEL classification: M48

* Corresponding author's e-mail: norsiah@unisza.edu.my 


\section{Introduction}

Despite risk-reporting attracting a great deal of interest following the major accounting scandals and corporate collapses of the early 2000s and the global financial crisis of 2008-2009 (Cole and Jones 2005; Kirkpatrick 2009), less attention has been paid to empirical research into CRD in the annual reports (Linsley and Shrives 2006). Moreover, most empirical studies have been conducted in developed countries such as the U.S (Elmy et al. 1998; Fang 2010), the U.K (Abraham and Cox 2007; Linsley and Shrives 2006), Italy (Beretta and Bozzolan 2004), Canada (Lajili and Zeghal 2005), and Japan (Konishi and Ali 2007; Mohobbot 2005). In contrast, there is a dearth of research on risk reporting in emerging countries in general and in Arab countries in particular; so far, no study has examined CRD practices in non-financial companies in Saudi Arabia. Hence, this study attempts to fill the gap in the risk literature, especially for developing countries, by investigating the extent and nature of CRD and its determinants in Saudi Arabia's non-financial listed companies.

This study is motivated, firstly, by the call made by Dobler et al. (2011) for more research into the drivers of CRD in emerging markets. Unlike developed economies, emerging markets are less efficient and suffer from a lack of compliance, regulations, enforcement, and transparency, with greater behavioural variations (Al Maghzom et al. 2016a; Richardson and Welker 2001). Thus, more research into risk reporting practices would contribute to the disclosure literature (Al-Maghzom et al. 2016b). Secondly, and more specifically, this study is encouraged by the call made by Habbash et al (2016) and Al-Maghzom et al. (2016a, b) for further investigation into the risk reporting practices of Saudi listed companies, since Saudi Arabia suffers from a lack of transparency and a low level of awareness of CRD, because corporate governance and CRD practices are still relatively new topics (Alamri 2014). Furthermore, the unique context of Saudi Arabia, in terms of its legal system and cultural dimensions, which are expected to have different and mixed effects on CRD, is another motivation to explore the reality of the risk disclosure practices and their determinants. Thirdly, on 25 April 2016, Saudi Arabia announced the Saudi Vision 2030. This is an ambitious economic plan intended to confirm the kingdom's status at the heart of the Arab and Islamic worlds as the investment power house and the hub connecting three continents. The vision adopts an open economic philosophy based on the market economy and the liberalisation of trade. Embracing best practices of transparency and accountability are among the main pillars of this plan, to protect investors, minimise agency problems, and attract domestic and foreign funds. Thus any research into corporate disclosure, in general and CRD, in particular, would be considered as a response to enhance the Saudi vision, since risk disclosure increases transparency, enhances investors' confidence, and obtains external funds at a lower cost of capital.

Added to this, Saudi Arabia is the largest economy in the Middle East, a major G20 economy and the largest oil producer in the world, as well as playing host to some of the world's largest multinationals (Al-Matari et al. 2015; Al-Bassam et al. 2015). According to the World Federation of Exchange's report in 2014, the market value of an average company in Saudi Arabia is about twice that of any average company globally. Moreover, the Saudi Stock Exchange's crash at the beginning of 2006 created a serious question 
about the effectiveness of corporate disclosure, including risk-related information, as a presumed monitoring device to protect investors. Finally, Saudi's accounting standards clearly reflect the great interest of the Saudi accounting authorities to raise and enhance the level and quality of disclosure in the companies' annual reports, including CRD. However, there is no specific standard, so far, to regulate risk management and risk reporting. These factors make the investigation of CRD practices in Saudi Arabia an interesting issue.

This study differs from the previous research in several ways. First, unlike a western business environment, this study is conducted in a developing and Islamic country, with a unique setting in an environment of conflict between secrecy, as a key feature of the Saudi accounting system (Gray 1988), versus transparency, as a key pillar of the Islamic accountability framework. Thus, this study would add to the literature by demonstrating to what extent Gray's (1988) model of accounting values is applicable against the strong Islamic accountability framework of Saudi Arabia, as well as the possibility of generalisation on Arab and Islamic countries.

Second, instead of investigating all the classes of corporate disclosure, this study specifically focuses on CRD, which has received limited attention from researchers, notably in developing countries.

Third, while most previous studies have focused narrowly on one aspect of CRD, such as financial risk disclosure (e.g., Marshall and Weetman 2008) or non-financial risk disclosure (e.g., Padia 2012), this study investigates both financial and non-financial risk disclosure to provide a comprehensive view of CRD.

Fourth, unlike prior studies that employed a single theoretical perspective (Al-
Maghzom et al. 2016b; Amran et al. 2009), the current study adopts a multiple theoretical framework, including the agency theory, the resource dependence theory, the political cost theory and the signaling theory, to provide a richer explanation of CRD and its determinants.

Fifth, this study differs from previous risk disclosure studies in Arab countries, such as in Kuwait (Al-Shammari 2014), Bahrain (Mousa and Elamir 2013), the United Arab Emirates (Hassan 2009), Egypt (Mokhtar and Mellett 2013), and the Gulf Cooperation Council (GCC) countries (Abdallah et al. 2015) by being the first study to investigate CRD based on a longitudinal analysis using a panel data fixed effects technique over 4 years, to obtain further insights and informative outcomes.

Sixth, this study is distinct from AlMaghzom et al.( 2016a,b) by investigating CRD in the annual reports of Saudi Arabia's non-financial listed companies using content analysis to measure the extent and nature of CRD, while Al-Maghzom et al.(2016a,b) have only focused on Saudi listed banks using a dichotomous procedure to measure the level of CRD.

The current study contributes to the existing CRD literature as follows: firstly, this study seeks to fill part of the stated research gap in the risk literature by providing a starting point for research into CRD practices in Saudi Arabia, by being the first study with such disclosures. Secondly, exploring the extent and nature of CRD will extend our understanding of risk reporting practices in a country with conflicting factors towards disclosure, namely, secrecy which is a key feature of the Saudi accounting system (Gray 1988) versus transparency which is a key pillar of the Islamic accountability framework. Thirdly, the 
results of this study are applicable to other GCC and Arab countries which have similar social, economic and institutional characteristics. The results may also contribute to the accounting literature on Emerging Markets (EM). This may assist the national and international standard-setters and policy makers to improve corporate governance practices and risk reporting. Lastly, this study is deemed to add to the existing extremely limited literature on CRD in Arab countries, in general and Saudi Arabia in particular.

This paper is organised as follows. The following section briefly reviews the relevant literature related to CRD practice and the hypotheses' development. The next section describes the research's methodology. The subsequent section presents and discusses the results of the study. The managerial and regulation implications of the study are demonstrated in the next section. The final section concludes the study and highlights the limitations and future research.

\section{Literature Review and Hypotheses Development}

One of the most difficult issues when conducting risk disclosure studies is the definition of risk, because different definitions of risk may lead to different content and different types of risk that should be disclosed. While there is no consistent and standard definition of CRD, the majority of the previous literature focused on two definitions of risk (Hassan 2011), which are the pre-modern risk definition (one sided-risk definition) that only reflects the negative dimension's effect of risk on a company's outcomes, and the modern risk definition (two sided-risk definition) that reflects both the negative as well as the positive dimensions. The pre-mod- ern risk definition, for example, is consistent with the definition of risk by the Financial Reporting Release No. 48, which requires listed companies to disclose qualitative and quantitative information about market risks, including potential losses from negative changes in interest rates, foreign exchange rates and commodity and equity prices (Securities and Exchange Commission 1997).

Although there are still authors in the modern era who use the pre-modern definition of risk, current analyses of risk are dominated by the modern definition, which is consistent with Lupton's (1999) perspective for a comprehensive understanding of risks surrounding a company, including both the potential for gain and exposure to loss. For example, Beretta and Bozzolan (2004, p. 269) define risk disclosure as "the communication of information concerning a firm's strategies, operations, and other external factors that have the potential to affect expected results." Furthermore, Linsley and Shrives (2006, p. 402) introduced a broad two-sided definition of risk reporting as those disclosures that:

"... inform the reader of any opportunity or prospect, or of any hazard, danger, harm, threat or exposure that has already impacted upon the company or may impact upon the company in the future or of the management of any such opportunity, prospect, hazard, harm, threat or exposure."

This definition is widely adopted by previous studies of CRD (e.g., Dobler et al. 2011; Mokhtar and Mellett 2013; Probohudono et al. 2013; Vandemaele et al. 2009; Zhang et al. 2013). The current study also adopts this definition to analyse and measure CRD in Saudi listed companies.

The importance of CRD is well documented in the risk literature. It has been argued that the corporate disclosure of risks and the way in which these risks are identi- 
fied, managed, analysed and evaluated would reduce agency conflicts by mitigating any information asymmetry between managers and stakeholders and between majority and minority shareholders (Beretta and Bozzolan 2004; Linsley and Shrives 2000; Oliveira et al. 2013). Thus, CRD increase the stakeholders' confidence in the company and its management, which in turn, reduces the cost of capital and consequently maximizes the company's value and the shareholders' wealth (Botosan 1997; Linsley and Shrives 2000; Solomon et al. 2000).

Despite the remarkable importance and benefits of CRD for users, the evidence still shows that, on the one hand, CRD studies are still relatively limited (Dobler et al. 2011) and on the other, that these studies conclude that risk disclosure in the corporate annual reports remains inadequate to meet the increased needs of interested parties (e.g., Abraham and Cox 2007; Amran et al. 2009; Beretta and Bozzolan 2004; Hassan 2009; Linsley and Shrives 2006; Mokhtar and Mellett 2013; Mousa and Elamir 2013; Oliveira et al. 2011a; Probohudono et al. 2013; Solomon et al. 2000). Past studies reveal that the content of CRD suffers from several weaknesses, by being too brief, generic and scattered, thus becoming neither sufficient nor effective. The CRD also lacks in comparability, transparency, uniformity and coherence as well as being backwardlooking and qualitative in nature. Thus, the current trend of risk disclosure often outweighs the expected nature, by being forwardlooking, quantitative, non-financial, monetary, bad, specific time and oriented risk disclosure. Moreover, there are considerable variations in the disclosure of risk sources and risk-management practices.

Previous risk disclosure studies investigating the association between CRD and firm-specific characteristics are limited and basically have been conducted in developed countries with well-established risk reporting regulations, such as the U.S (Dobleret al. 2011), the U.K (Linsley and Shrives 2006), Italy (Beretta and Bozzolan 2004), Portugal (Oliveira et al. 2011), and Japan (Konishi and Ali 2007). However, very few studies into the impact of firm-specific characteristics on CRD have been undertaken in Arab countries such as in Bahrain (Mousa and Elamir 2013), Kuwait (Al-Shammari 2014), the United Arab Emirates (El-Kelish and Hassan 2014). These referenced studies provided evidence that various firm-specific characteristics affect CRD. The current study extends the risk reporting studies by providing evidence of the CRD practices and their drivers in Saudi listed companies.

Relying on multiple accounting theories, such as the agency theory, the resource dependence theory, the political cost theory and the signaling theory, in addition to empirical evidence, three hypotheses are developed by this study to explain and examine the impact of firm-specific characteristics on CRD.

\section{Firm Size and $C R D$}

According to the resource dependence theory, larger companies have a stronger motivation to disclose more valued risk information to the market-interested parties, as they have more sources, including higher finance and larger and better qualified boards and management teams that can bear the cost of more disclosures. Similarly, the political cost theory suggests that larger companies attract more attention from the political sector and other stakeholders, which leads to higher political costs. Therefore, providing more disclosure, including risk details, is a way to mitigate these costs (Frendy and Kusuma 2011; Oorschot 2009). However, 
large and profitable companies are also associated with low quality disclosures, as they are more likely to engage in fraudulent financial reporting to reduce profits and avoid attention by politicians and related costs (Nor et al. 2010).

The empirical evidence reveals mixed results regarding the relationship between the size of a firm and CRD. For example, Ismail and Rahman (2011), Barakat and Hussainey (2013), Ntim et al. (2013), and Dominguez and Gamez (2014) found a positive impact of firm size on CRD. However, Beretta and Bozzolan (2004), Hassan (2009), and Mokhtar and Mellett (2013), found an insignificant relationship between the two variables. As reported by the World Federation of Exchange in 2014, the market value of an average company in Saudi Arabia is about twice that of any average company globally. This may indicate the ability of larger Saudi companies to improve their reporting systems as they possess the resources and capital to bear the cost of disclosing at a higher level their risk-related information. Accordingly, it can be hypothesized that:

$$
\begin{aligned}
& H_{i} \text { : There is a positive relationship between firm } \\
& \text { size and CRD. }
\end{aligned}
$$

\section{Leveraged and CRD}

The agency theory suggests that higher leveraged companies are more likely to disclose more risk information, to reduce their higher agency costs in terms of their higher monitoring activities, notably by debt holders, and higher capital cost (Jensen and Meckling 1976). In a complementary view, the stakeholder theory and signaling theory assume that leveraged companies have a greater motivation to provide more risk disclosure, in order to assure debt holders and other creditors, as their key stakeholders and signal their ability to manage different risks faced by the company and fulfill their obligations (Foster 1986).

Empirically, Taylor et al. (2008) found a positive relationship between leverage and CRD, while Abraham and Cox (2007) and Linsley and Shrives (2006) found an insignificant association between the two variables. However, Ntim et al. (2013) found that leveraged companies disclose less risk information. Following the disclosure theories' expectations, it can be hypothesised that:

$\mathrm{H}_{2}$ : There is a positive relationship between leverage and $C R D$.

\section{Audit Firm Size and CRD}

The agency theory suggests that external auditors have a strong influence in mitigating agency conflicts between managers and investors through enhancing corporate disclosure (Jensen and Meckling 1976), as they enjoy a high level of independence from their clients and have strong incentives to maintain their reputation as providers of a highquality audit service (DeAngelo 1981). On the other hand, the resource dependency theory suggests that large audit firms are more likely to enhance the disclosure's quality as they have more resources, expertise, and knowledge, which enables them to be familiar with new accounting requirements, and places them in a good position to persuade management for more disclosure (Kent and Stewart 2008).

Ahmed and Nicholls (1994) and AlShammari (2008) found that audit firms' size positively influences the level of corporate disclosure. Furthermore, Nor et al. (2010) document a negative impact of the size of the audit firm on fraudulent financial reporting. On the other hand, the study of Ahmad et al. (2011) indicated that companies audited 
by small-sized audit firms engage in more misstatements in their financial reporting. Based on the theoretical and practical expectations, it can be hypothesized that:

\section{$H_{3}$ : There is a positive relationship between the au- dit firm's size and $C R D$.}

\section{Methods}

The initial sample of this study consisted of 558 company annual reports from listed companies on the Saudi Stock Exchange (Tadawul) over the period of 20082011. After excluding financial companies (109), and non-financial companies with incomplete data (98), the final sample comprises of 307 non-financial company-year observations. Data on firm-specific characteristics and CRD are collected from the companies' annual reports.

This study applies an unbalanced panel data analysis to investigate the relationship between firm-specific characteristics and CRD. The firms' fixed effects regression model for CRD is as follows:

$$
\begin{aligned}
\text { CRD }_{\text {it }}= & \beta_{0}+\beta_{1} \text { FSIZE }_{i t}+\beta_{2} \text { LEV }_{i t} \\
& +\beta_{3} \text { AUDFSIZE }_{i t}+\varepsilon_{i t}
\end{aligned}
$$

Where:

$\begin{array}{ll}\text { CRD : } & \text { Corporate Risk Disclosure } \\ \text { FSIZE }: & \text { Firm Size } \\ \text { LEV : } & \text { Leverage } \\ \text { AUDFSIZE }: & \text { Audit Firm Size } \\ \varepsilon: & \text { Error term }\end{array}$

To check whether the Ordinary Least Squares (OLS) or panel data (fixed and random effects) technique is more appropriate to analyse the data set, Lagrange's Multiplier (LM) approach was applied to test for the presence of random effects by comparing a random effects model with the OLS. In addi- tion, the F-test was also conducted to check for fixed effects by comparing a fixed effects model with the OLS. The results of both tests (LM and F-test) showed a significant P-value, which strongly indicates the presence of both the random and fixed effects. Therefore, the null hypothesis is rejected indicating that the application of panel data models (fixed and random effects models) is more appropriate than the OLS.

The Hausman test (Hausman 1978) compares the random effects model to the fixed effects model, based on the null hypothesis that the individual effects are uncorrelated with the regressors. Thus, if the null hypothesis is not rejected, the random effects model is favoured. Otherwise, the fixed effects model is preferred. The result of the Hausman test showed a significant P-value, which rejects the null hypothesis, indicating that the fixed effects model is more appropriate to analyze the data set of this study.

Prior to running the panel data analysis, the multivariate analysis assumptions, such as outliers, normality, linearity, multicollinearity, heteroscedasticity, and autocorrelation, have been checked and corrected. The Z-score test (Hair et al. 2010; Tabachnick and Fidell 2007) indicates some patterns of univariate outliers, which are labelled for further research. The Mahalanobis' distance test (Kline 2011; Tabachnick and Fidell 2007) was applied to detect multivariate outliers. The result indicates the absence of multivariate outliers. To check the normality distribution of the residual, this study used graphical and numerical tests. Skewness and kurtosis are among the most common statistical tests for normality. The data can be considered as normally distributed if the values of skewness and kurtosis are zero (Tabachnick and Fidell 2007). The results show that the skewness and kurtosis values 
of all variables exceed the threshold of normality. A further test of normality was performed using a numerical test, namely, the Shapiro-Wilk test. The result shows a significant P-value, which rejects the null hypothesis that the data is normally distributed.

Data transformation is the common procedure to mitigate the outliers and meet the assumption of normality (Hair et al. 2010; Tabachnick and Fidell 2007). Following Hair et al. (2010), this study applied all the possible methods of data transformations for each variable, and then chose the variable that had the best data distribution among the original and transformed variables. Table 1 presents the original and transformed variables and data transformation methods used in this study.

After data transformation, the univariate outliers were significantly reduced, to bring them approximately within the criteria suggested by (Hair et al. 2010). The new tests of skewness and kurtosis for the transformed variables show a significant improvement. In addition, the P-value of the Shapiro-Wilk test became insignificant at 0.05 percent, indicating that the null hypothesis, that the data is normally distributed, cannot be rejected.

The next test was to check the linearity assumption. The result of the scatter plots did not strongly indicate a clear departure from linearity. Multicollinearity is another assumption that should be checked and corrected. A correlation matrix and Variance Inflation Factor (VIF) were used to detect multicollinearity between independent variables. Table 2 shows that multicollinearity is not a problem since the highest value is 0.495 between firm size and audit firm size, which is less than the threshold (0.90) of multicol-

Table 1. Original and Transformed Variables and Data Transformation Methods

\begin{tabular}{lccccc}
\hline \multirow{2}{*}{ Variable } & \multicolumn{2}{c}{ Original Data } & \multicolumn{2}{c}{ Transformed Data } & $\begin{array}{c}\text { Best } \\
\end{array}$ \\
\cline { 2 - 4 } & Skewness & Kurtosis & Skewness & Kurtosis & $\begin{array}{c}\text { Transformation } \\
\text { Method }\end{array}$ \\
\hline $\begin{array}{l}\text { Corporate Risk } \\
\text { Disclosure (CRD) }\end{array}$ & 1.253 & 1.837 & -0.002 & 0.139 & Log \\
Leverage (Lev) & 0.225 & -0.992 & & & None \\
$\begin{array}{l}\text { Firm Size (FSize) } \\
\text { Audit Firm Size } \\
(\text { AudFSize) }\end{array}$ & 5.735 & 35.784 & 0.644 & 0.198 & Log \\
\hline
\end{tabular}

Table 2. Pearson Correlation Matrix

\begin{tabular}{lcccc}
\hline & CRD & Lev & FSize & AudFSize \\
\hline CRD & 1 & & & \\
FSize & $0.481^{* *}$ & 1 & & \\
Lev & $0.357^{* *}$ & $0.491^{* *}$ & 1 & \\
AudFSize & $0.463^{* *}$ & $0.444^{* *}$ & $0.495^{* *}$ & 1 \\
\hline$* *$, Correlation is significant at the 0.01 level (2-tailed).
\end{tabular}

Table 3.Results of VIF and Tolerance Tests

\begin{tabular}{lcc}
\hline Variable & VIF & 1/VIF \\
\hline Lev100 & 1.51 & 0.663 \\
AudFSize & 1.43 & 0.701 \\
\hline FSize & 1.42 & 0.706 \\
\hline Mean VIF & 1.45 & \\
\hline
\end{tabular}


linearity suggested by (Hair et al. 2010; Tabachnick and Fidell 2007).

The dependent variable $C R D$ is the logarithm of the total number of risk-related sentences. FSize is the logarithm of company total assets; Lev is the rate of total liabilities divided by total assets; AudFSize is a dummy variable, 1 if the company is audited by the Big 4 audit firm and 0 otherwise. Furthermore, the VIF test, as shown in Table 3, confirmed the absence of a multicollinearity problem as the highest value (1.51) is far less than the threshold value of VIF (10) (Hair et al. 2010).

To test heterosedasticity and autocorrelation in the fixed effects model, the modified Wald statistic test for group-wise heteroscedasticity in the fixed effects regression model (Greene 2003) and the Wooldridge test (Wooldridge 2002) for autocorrelation are applied, respectively. The results show significant P-values, indicating the presence of both heteroscedasticity and autocorrelation, which need to be solved or controlled. Therefore, this study estimates the fixed effects model of CRD, based on the estimator of Rogers (1993) clustered at the firm level, as it produces an estimator that is robust to cross-sectional heteroscedasticity and withinpanel correlation.

Endogeneity is another concern in corporate disclosure studies (Elshandidy and Neri 2015; Ntim et al. 2013). However, using fixed-effects models is a common remedy for endogeneity problems (e.g., Brown et al. 2011; Guest 2009).

\section{Measurement of Dependent Variable}

The content analysis method is used in this study to measure CRD, which has been widely used by prior CRD studies (e.g., Abraham and Cox 2007; Amran et al. 2009; Lajili and Zeghal 2005; Mousa and Elamir 2013; Ntim et al. 2013; Zhang et al.2013). Applying the content analysis requires classifying the content into appropriate categories and related items and identifying the appropriate unit of coding.

In this study, a new model of risk categorization consisting of 7 categories and 60 items was developed to analyze and measure all the types of risk that are faced by the selected sample. This model is built based on an extensive review of the risk-related regulations and previous studies on risk classification, as well as taking into account the Saudi regulatory environment in which the sample companies operate, including the laws, standards, and governance regulations. Appendix A presents the risk-classification model adopted by this study.

Following the majority of CRD studies (e.g., Linsley and Shrives 2006; Mokhtar and Mellett 2013; Ntim et al. 2013), this study employs the number of sentences as a unit of analysis to measure the level of CRD and to code it into the intended categories and items, as it is more reliable than other units of analysis (Milne and Adler 1999).

With respect to the nature or content of CRD, the number of risk-related sentences are classified into four quality dimensions, namely, the type of risk disclosure (financial versus non-financial), the form of disclosure (quantitative versus qualitative), the time frame of the disclosure (future versus past, present, or non-time-specific), the type of news (bad versus good and neutral) (Linsley and Shrives 2006; Mokhtar and Mellett 2013; Ntim et al. 2013). 


\section{Validity and Reliability of the Measurement}

To achieve the validity of the measurement, the risk classification model had been discussed with two independent academics to take advantage of their experience in reviewing and developing the coding scheme and strengthening its validity. The reliability of the measurement can be achieved by using multiple coders to code the same content, or by employing a single coder with adequate training (Milne and Adler 1999). Since the annual reports of the selected sample are mostly written in Arabic, a single coder (i.e., the researcher) coded the risk-related information in the annual reports, after spending sufficient time practicing the coding process in order to become familiar with the coding scheme. A clear list of decision rules (Linsley and Shrives 2006) as shown in Appendix B is also used to guide the coder in analyzing the content into the intended categories and items.

\section{Measurement of Independent Variables}

The independent variables involved in this study are firm size, leverage, and audit

Table 4. Measurement of independent variables

\begin{tabular}{ll}
\hline $\begin{array}{c}\text { Independent } \\
\text { Variables }\end{array}$ & \multicolumn{1}{c}{ Measurement } \\
\hline Firm size (FSize) & $\begin{array}{l}\text { Natural logarithm of total } \\
\text { assets }\end{array}$ \\
Leverage (Lev) & $\begin{array}{l}\text { Ratio of total debt to total } \\
\text { assets }\end{array}$ \\
Audit firm size & $\begin{array}{l}\text { Dummy variable of one if } \\
\text { the company is audited by } \\
\text { the Big 4 Audit firms, and } \\
\text { zero otherwise }\end{array}$ \\
\hline
\end{tabular}

firm size. Table 4 summarizes the measurement of these independent variables.

\section{Results and Discussion}

\section{Descriptive Statistics}

Table 5 shows that CRD varies greatly among companies and ranges from a minimum of 22 sentences to a maximum of 282 sentences, with a mean of 84.97 sentences per annual report and a standard deviation of 44.451 .

This level of CRD is higher than those reported in some developing and developed countries, such as Egypt (Mokhtar and Mellett 2013), Malaysia (Amran et al. 2009), and Italy (Greco 2012). However, it is lower than those disclosed in the U.S, Canada, the U.K, and Germany (Dobler et al. 2011). The relatively high level of CRD in Saudi Arabia may reflect the strong commitment to Islamic Sharia requirements by the country, due to the overriding presence of Islam, which is assumed to encourage the Saudi accounting system to provide a higher level of disclosure and more transparency as a key pillar of the Islamic accountability framework. However, the findings from Table 6 reflect a low quality level of CRD, according to the four dimensions of quality. Non-financial, qualitative, past, present, or non-time-specific and neutral risk disclosures far outweigh the financial, quantitative, future, and bad risk disclosures. The low quality of CRD may reflect the relatively high level of uncertainty avoidance and secrecy proposed by Hofstede (1984) as a key cultural dimension of Saudi society, and a basic accounting value suggested by Gray (1988) that affects the Saudi accounting system and disclosure practice. Although the risk information disclosed by 
GadjahMada International Journal of Business-September-December, Vol. 19,No. 3, 2017

Table 5. Descriptive Statistics for Dependent and Independent Variables

\begin{tabular}{lcccccc}
\hline \multicolumn{1}{c}{ Variable } & Min & Max & Mean & Std. Dev. & Skewness & Kurtosis \\
\hline $\begin{array}{l}\text { Total number } \\
\text { of CRD Sentences }\end{array}$ & 22 & 282 & 84.97 & 44.451 & 1.253 & 1.837 \\
General Risk Information & 0 & 53 & 8.78 & 8.219 & 2.299 & 7.366 \\
Accounting Policies & 4 & 68 & 24.52 & 13.243 & 1.017 & 0.64 \\
Financial Instruments & 0 & 21 & 3.15 & 4.052 & 1.501 & 2.59 \\
Derivatives Hedging & 0 & 25 & 3.4 & 5.471 & 2.055 & 3.49 \\
Segment Information & 0 & 43 & 6.92 & 8.448 & 1.602 & 3.058 \\
Operational Risk & 2 & 126 & 24.83 & 17.961 & 1.776 & 4.258 \\
Financial Risk & 0 & 57 & 13.02 & 9.545 & 1.05 & 2.201 \\
\hline Lev & 0.22 & 84.98 & 37.69 & 21.15 & .225 & -.992 \\
FSize & 97,182 & $332,783,648$ & $13,014,026$ & $41,195,766$ & 5.735 & 35.784 \\
AudFSize & 0 & 1 & 0.68 & 0.47 & -0.763 & -1.427 \\
\hline
\end{tabular}

Table 6. Characteristics of CRD Sentences

\begin{tabular}{llcccccc}
\hline CRD Characteristics & \multicolumn{1}{c}{ Code } & $\begin{array}{c}\text { CRD } \\
\text { Sentences }\end{array}$ & (\%) & Min & Max & Mean & $\begin{array}{c}\text { Std. } \\
\text { Dev. }\end{array}$ \\
\hline $\begin{array}{l}\text { Type of disclosure } \\
\text { (Risk categories) }\end{array}$ & Financial & 3,996 & 0.153 & 0 & 57 & 13.02 & 9.545 \\
& Non-financial & 22,089 & 0.847 & 16 & 256 & 71.95 & 38.531 \\
\hline \multirow{2}{*}{ Form of disclosure } & Quantitative & 6,649 & 0.255 & 0 & 101 & 21.66 & 16.005 \\
& Qualitative & 19,436 & 0.745 & 5 & 229 & 63.31 & 36.504 \\
\hline \multirow{2}{*}{ Time frame } & Future & 3,008 & 0.115 & 1 & 50 & 9.8 & 7.487 \\
& Past, present, & 23,077 & 0.885 & 21 & 239 & 75.17 & 39.547 \\
& or non-time-specific & & & & & & \\
\hline \multirow{2}{*}{ Type of news } & Bad & 3,665 & 0.14 & 2 & 42 & 11.94 & 7.364 \\
& Good & 8,233 & 0.316 & 3 & 127 & 26.82 & 18.155 \\
& Neutral & 14,187 & 0.544 & 8 & 148 & 46.21 & 26.214 \\
\hline
\end{tabular}

Saudi companies is of low quality, it is consistent with the previous evidence (e.g., Dobler et al. 2011; Linsley and Shrives 2006; Ntim et al. 2013; Oliveira et al. 2011b) that documents similar results. This implies that higher amounts of disclosure may not necessary mean higher levels of quality. 


\section{Bivariate Analysis}

As shown in Table 2, the results of the correlation matrix support the hypotheses, as all the independent variables have a significant positive correlation with CRD. These findings are also consistent with the theoretical perspective and empirical evidence.

\section{Multivariate Analysis}

Table 7 presents the results of the firm fixed effects regression analysis for CRD. The F-value of the model is statistically significant at the 1 percent level and the $\mathrm{R}^{2}$ within is 20.4 percent. The value of $\mathrm{R}^{2}$ within indicates that the independent variables involved in the regression model explain 20.4 percent of the variation of CRD.

The results show a significant positive relationship between firm size and CRD. This implies that the larger Saudi companies are more likely to disclose a higher level of CRD. This result is explainable by multiple disclosure theories. Furthermore, the result is consistent with the empirical evidence from Saudi Arabia, such as Mgammal (2011) and Al-Janadi et al. (2013) who found a positive impact of firm size on voluntary disclosure. Regarding CRD, the results are consistent with the previous evidence on the positive impact of firm size on CRD in GCC countries (Abdallah et al. 2015), the U.S., Canada, the U.K., and Germany (Dobler et al. 2011; Elshandidy et al. 2015), Indonesia, Malaysia, Singapore, and Australia (Probohudono et al. 2013), and Japan (Mohobbot 2005).

For leverage, the results show an insignificant relationship between leverage and CRD. This result is not consistent with the theoretical perspective. However, empirical evidence from Saudi Arabia shows mixed results between leverage and disclosure. While Mgammal (2011) reports a positive impact of leverage on voluntary disclosure, Habbash and Al-Moataz (2013) find a negative relationship between leverage and the audit committee's effectiveness. However, an insignificant association between leverage and disclosure is reported by Alsaeed (2006).

The insignificant impact of leverage in this study may be due to the fact that creditors have the ability to access internal information and satisfy their needs via sharing private risk information with management, in-

\section{Table 7. Results of the Firm Fixed Effects Regression Analysis for CRD}

\begin{tabular}{lccc}
\hline Variables & $\begin{array}{c}\text { Predicted } \\
\text { Sign }\end{array}$ & Coefficient & t-statistic \\
\hline Constant & & -1.584 & $-2.05^{* *}$ \\
FSize & + & 0.539 & $4.32^{* * *}$ \\
Lev & + & -0.000 & -0.67 \\
AudFSize & + & 0.082 & $2.24^{* *}$ \\
F- value & & & $11.11^{* * *}$ \\
$\mathrm{R}^{2}$ within & & & 0.204 \\
$\mathrm{~N}$ & & & 307 \\
\hline
\end{tabular}


stead of relying on the annual reports, which in turn, reduces the management's motivation for more public disclosure (Lakhal 2007). This conclusion is consistent with the stakeholder theory that says creditors are a key financial stakeholder with the power to convince highly leveraged companies to respond to their need for risk-related information, even if it is done privately (Roberts 1992). An opposite explanation for the insignificant impact of leverage, as a proxy of creditors, is due to the poor role of creditors in influencing CRD.

Regarding the audit firm's size, the results reveal a significant positive impact of audit firm size on CRD. Saudi companies audited by the Big 4 audit firms tend to provide more CRD. This finding supports the argument that the type of auditor is a key factor in explaining the variations in corporate disclosure. Alsaeed (2006) and Al-Janadi et al. (2013) find a positive relationship between the audit firm's size and voluntary disclosure in Saudi Arabia. Large audit firms, such as the Big 4, are expected to be associated with a higher level of corporate disclosure because they enjoy considerable independence from their clients and have strong incentives to maintain their reputation as providers of a high-quality audit service (DeAngelo 1981). Thus, large audit firms are being forced or persuaded to encourage companies to comply with accounting regulations and engage in more disclosure.

\section{Managerial and Regulation Implication}

Investigating the current state of CRD has important implications for policy makers, regulators and the financial service authorities in Saudi Arabia, in their efforts to ensure information adequacy and enhance the capital market's efficiency. This study informs the Saudi regulatory bodies of the current practice of CRD in Saudi listed companies and its determinants. For example, the relatively high level of CRD implies that efforts by the Saudi Arabian Stock Exchange (Tadawul), the Capital Market Authority (CMA), and the Saudi Organization for Certified Public Accountants (SOCPA) to enhance transparency have had some positive impacts on the CRD practices of Saudi listed companies. However, the low quality of the risk information disclosed reflects the inadequacy of CRD, which suggests that new riskrelated regulations and their enforcement may need to be strengthened further. Regulatory authorities should devise the appropriate means to enhance companies' involvement in risk reporting practices. In this regard, efforts should be focused on developing a framework of risk reporting and guidance for companies to disclose relevant risk information that can be used by those seeking to evaluate the risk profile of a company. Regulatory bodies should provide companies with a sound framework for risk reporting, including clear guidance for identifying, evaluating, managing and disclosing the risk profile of the company. Moreover, empirical evidence on the determinants of CRD suggests that regulators should be particularly concerned about the disclosure needs of the users of smaller companies and companies with a high risk level that are not audited by one of the Big 4 audit firms.

Saudi companies' managers may also use the findings of this study to check the amount and quality of risk information in their annual reports, to ensure funds' sourcing and enhance the company's market value. Companies have to focus on the users' need for information and disclose more accurate and reliable financial, quantitative, future and 
bad risk disclosures, rather than merely following a rigid list of risk-related items to be disclosed. The evidence indicates that Saudi investors face inadequate protection and a lack of transparency, in addition to a low level of awareness of the current and potential risks surrounding a company, because risk disclosure is a relatively new topic (Alamri 2014). Therefore, identifying the types of risk information disclosed and the way in which they are managed by different companies in different sectors, while also identifying the characteristics of the companies that disclose such information, will be useful to educate Saudi investors and companies alike about CRD practices. The practical implications from these findings for company managers and those preparing financial reports are that, in order to keep investors satisfied, smaller companies and companies audited by nonBig 4 audit firms should consider the investors' demands for risk information so they can make informed investment decisions.

\section{Summary and Conclusion}

This study aims to explore the level and nature of CRD in the annual reports of Saudi Arabian (non-financial) listed companies. In addition, the study investigates the impact of Saudi firm-specific characteristics on CRD. The descriptive analysis indicates that Saudi companies provide a moderate level of CRD among the developing and developed countries. Nevertheless, the content is found to be of a low quality, being as it is mostly composed of non-financial, qualitative, past, present, or non-time-specific and neutral disclosures. In the absence of a special standard for risk reporting, the regulatory bodies should provide companies with a sound framework for risk reporting, including clear guidance for identifying, evaluating, managing and disclos- ing the risk profile of the company. The Saudi regulatory bodies are encouraged to educate investors and the public about the importance of risk reporting.

The results from the panel data analysis support the positive role of firm size and audit firm size as key determinants of CRD in Saudi Arabia. As larger companies and companies audited by the Big 4 audit firms do disclose more risk-related information in their annual reports, users should be cautious when dealing with smaller companies and companies audited by non-Big 4 audit firms and may have to consider different sources of information, in addition to the annual reports. However, this study fails to find a significant impact of leverage on CRD. This result suggests that the regulators and companies' managers should be particularly concerned about the disclosure needs of users of highly leveraged companies, such as debt holders and other creditors.

Despite the positive influence of firm size and audit firm size on the level of CRD, this result may not be consistent with the expected impact of the huge size of Saudi companies on the level and content of their CRD. While the size of Saudi companies is double the global average for the size of a company, the results reveal a moderate level of CRD, which is of a low quality compared to other developing and developed countries. Furthermore, the descriptive statistics reveal that only 68 percent of Saudi listed companies were audited by at least one of the Big 4 audit firms, while the others were audited by local or non-Big 4 audit firms. This suggests that managers and auditors should make use of the financial resources, expertise and capabilities available to Saudi companies, to enhance their transparency in general and CRD in particular. 
This study contributes to the risk literature by providing an initial understanding of CRD practices and their determinants in Saudi Arabia, where risk reporting is still in its infancy. However, the results of this study are not free from some limitations. First, this study focuses on the annual reports as the sole source of CRD. However, other alternative means, such as the interim reports and websites, may be subjected to future research. Second, applying the content analysis ap- proach, including the classification and scoring process of CRD, involves inherent subjective judgements that cannot be eliminated. Third, as this study focuses on the quantity of CRD, future research may investigate the quality of CRD. Last, future research may expand the understanding of CRD practices in the Saudi context by examining other determinants of CRD, such as corporate governance mechanisms and ownership structures.

\section{References}

Abdallah, A. A. N., M. K. Hassan, and P. L. McClelland. 2015. Islamic financial institutions, corporate governance, and corporate risk disclosure in Gulf Cooperation Council Countries. Journal of Multinational Financial Management 31: 63-82.

Abraham, S., and P. Cox. 2007. Analysing the determinants of narrative risk information in UK FTSE 100 annual reports. British Accounting Review 39 (3): 227-248.

Ahmad, N., J. M. Nor, and N. M. Saleh. 2011. Tax audit and noncompliance behaviour amongst companies in Malaysia. 1st International Conference on Accounting, Business and Economics (ICABEC2011). Universiti Malaysia Terengganu.

Ahmed, K., and D. Nicholls. 1994. The impact of non-financial company characteristics on mandatory disclosure compliance in developing countries: The case of Bangladesh. International Journal of Accounting 29 (1): 62-77.

Alamri, M. A. 2014. Corporate governance and the Board of Directors in Saudi-listed companies. PhD thesis. University of Dundee. UK.

Al-Bassam, W. M., C. G. Ntim, K. K. Opong, and Y. Downs. 2015. Corporate boards and ownership structure as antecedents of corporate governance disclosure in Saudi Arabian Publicly Listed Corporations. Business and Society 54: 1-43.

Al-Janadi, Y., R. A. Rahman, and N. Haj Omar. 2013. Corporate governance mechanisms and voluntary disclosure in Saudi Arabia. Research Journal of Finance and Accounting 4 (4): 25-35.

Al-Maghzom, A., K. Hussainey, and D. Aly. 2016a. Corporate governance and risk disclosure: Evidence from Saudi Arabia. Corporate Omnership and Control Journal 13 (2): 145-166.

Al-Maghzom, A., K. Hussainey, and D. Aly. 2016b. The level of risk disclosure in listed banks: Evidence from Saudi Arabia. Corporate Ownership and Control 14 (1): 175-194.

Al-Matari, Y. A., A. K. Al-Swidi, and F. H. B. Fadzil. 2012. Corporate governance and performance of Saudi Arabia Listed Companies. British Journal of Arts and Social Sciences 9 (I): 1-30.

Alsaeed, K. 2006. The association between firm-specific characteristics and disclosure: The case of Saudi Arabia. Managerial Auditing Journal 21 (5): 476-496.

Al-Shammari, B. 2014. Kuwait corporate characteristics and level of risk disclosure: a content analysis approach. Journal of Contemporary Issues in Business Research 3 (3): 128-153.

Al-Shammari, B. 2008. Voluntary disclosure in Kuwait corporate annual reports. Review of Business Research 8 (1): 10-30. 
Amran, A., Bin, A. M. R., and B. C. H. M. Hassan. 2009. Risk reporting: An exploratory study on risk management disclosure in Malaysian annual reports. Managerial Auditing Journal 24 (1): 39-57.

Barakat, A., and K. Hussainey. 2013. Bank governance, regulation, supervision, and risk reporting: Evidence from operational risk disclosures in European banks. International Review of Financial Analysis 30: 254-273.

Beretta, S., and S. Bozzolan. 2004. A framework for the analysis of firm risk communication. The International Journal of Accounting 39 (3): 265-288.

Botosan, C. A. 1997. Disclosure level and the cost of equity capital. The Accounting Review 72 (3): 323-349.

Brown, P., W. Beekes, and P. Verhoeven. 2011. Corporate governance, accounting and finance: A review. Accounting and Finance 51 (1): 96-172.

Cole, C. J., and C. L. Jones. 2005. Management discussion and analysis: A review and implications for future research. Journal of Accounting Literature 24: 135-174.

DeAngelo, L. E. 1981. Auditor size and audit quality. Journal of Accounting and Economics 3 (3): 183-199.

Dobler, M., K. Lajili, and D. Zéghal. 2011. Attributes of corporate risk disclosure: An international investigation in the manufacturing sector. Journal of International Accounting Research 10 (2): 1-22.

Dominguez, L. R., and L. C. N. Gamez. 2014. Corporate reporting on risks: Evidence from Spanish companies. Revista de Contabilidad 17 (2): 116-129.

ElKelish, W.W., and M. K. Hassan. 2014. Organizational culture and corporate risk disclosure. International Journal of Commerce and Management 24 (4): 279-299.

Elmy, F. J., L. P. LeGuyader, and T. J. Linsmeier. 1998. A review of initial filings under the SEC's new market risk disclosure rules. Journal of Corporate Accounting and Finance 9 (4): 33-45.

Elshandidy, T., I. Fraser, and K. Hussainey. 2015. What drives mandatory and voluntary risk reporting variations across Germany, the UK and US? The British Accounting Review 47 (4): 376-394.

Elshandidy, T., and L. Neri. 2015. Corporate governance, risk disclosure practices, and market liquidity: comparative evidence from the UK and Italy. Corporate Governance: An International Review 23 (4): 331-356.

Fang, X. 2010. Informativeness of value-at-risk disclosure in the banking industry. PhD Thesis. University of Toronto, Canada.

Foster, G. 1986. Financial Statement Analysis. Englewood Cliffs, New Jersey: Prentice Hall.

Frendy, and I. W. Kusuma. 2011. The impact of financial, non-financial, and corporate governance attributes on the practice of global reporting initiative (GRI) based environmental disclosure. Gadjah Mada International Journal of Business 13 (2): 143-159.

Gray, S. J. 1988. Towards a theory of cultural influence on the development of accounting systems internationally. Abacus 24 (1): 1-15.

Greco, G. 2012. The management's reaction to new mandatory risk disclosure: A longitudinal study on Italian listed companies. Corporate Communications: An International Journal 17 (2): 113-137.

Greene, W. H. 2003. Econometric Analysis. New Jersey: Prentice Hall.

Guest, P. M. 2009. The impact of board size on firm performance: evidence from the UK. The European Journal of Finance 15 (4): 385-404.

Habbash, M., and E. Al-Moataz. 2013. Determinants of audit committee effectiveness in Saudi listed firms. The Journal of American Business Review 1 (2): 207-215.

Habbash, M., M. Hussainey, and A. E. A. Ibrahim. 2016. The determinants of voluntary disclosure in Saudi Arabia: An empirical study. International Journal of Accounting, Auditing and Performance Evaluation 12 (3): 213-236.

Hair, J. F., W. C. Black, B. J. Babin, and R. E. Anderson. 2010. Multivariate Data Analysis. New Jersey: Prentice Hall. 
Hassan, M. K. 2009. UAE corporations-specific characteristics and level of risk disclosure. Managerial Auditing Journal 24 (7): 668-687.

Hassan, W. M. 2011. Risk management practices: A comparative analysis between Islamic banks and Conventional banks in the Middle East. International Journal of Academic Research 3 (3): 288-295.

Hausman, J. A. 1978. Specification tests in econometrics. Econometrica 46 (6): 1251-1271.

Ismail, R., and R. Rahman. 2011. Institutional investors and board of directors' monitoring role on risk management disclosure level in Malaysia. The IUP Journal of Corporate Governance 10 (2): 37-61.

Jensen, M. C., and W. H. Meckling. 1976. Theory of the firm: Managerial behavior, agency costs and ownership structure. Journal of Financial Economics 3 (3): 305-360.

Kent, P., and J. Stewart. 2008. Corporate governance and disclosures on the transition to international financial reporting standards. Accounting and Finance 48 (4): 649-671.

Kirkpatrick, G. 2009. The corporate governance lessons from the financial crisis. OECD Journal: Financial Market Trends Report 1: 61-87.

Kline, R. B. 2011. Principles and Practice of Structural Equation Modeling. New York: The Guilford Press.

Konishi, N., and M. M. Ali. 2007. Risk reporting of Japanese companies and its association with corporate characteristics. International Journal of Accounting, Auditing and Performance Evaluation 4 (3): 263 285.

Lajili, K., and D. Zeghal. 2005. A content analysis of risk management disclosures in Canadian annual reports. Canadian Journal of Administrative Sciences 22 (2): 125-142.

Lakhal, F. 2007. Ownership structure and voluntary disclosures: the case of French-listed firms. Corporate Ownership and Control 5 (1): 131-138.

Linsley, P. M., and P. J. Shrives. 2000. Risk management and reporting risk in the UK. Journal of Risk 3 (1): 115-129.

Linsley, P. M., and P. J. Shrives. 2006. Risk reporting: A study of risk disclosures in the annual reports of UK companies. British Accounting Review 38 (4): 387-404.

Lupton, D. 1999. Risk. London: Routledge.

Marshall, A., and P. Weetman. 2008. Managing Interest Rate Risk and Foreign Exchange Risk: Disclosure of Objectives, Policies and Processes. London: ICAEW.

Mgammal, M. H. H. 2011. Voluntary disclosure and ownership structure among Saudi Arabia companies. Master Thesis. University Utara Malaysia.

Milne, M. J., and R. W. Adler. 1999. Exploring the reliability of social and environmental disclosures content analysis. Accounting, Auditing and Accountability Journal 12 (2): 237-256.

Mohobbot, A. 2005. Corporate risk reporting practices in annual reports of Japanese companies. Japanese Journal of Accounting 16 (1): 113-33.

Mokhtar, E. S., and H. Mellett. 2013. Competition, corporate governance, ownership structure and risk reporting. Managerial Auditing Journal 28 (9): 838-865.

Mousa, G. A., and E. A. H. Elamir. 2013. Content analysis of corporate risk disclosures/ : the case of Bahraini capital market. Global Review of Accounting and Finance 4 (1): 27-54.

Nor, J. M., N. Ahmad, and N. M. Saleh. 2010. Fraudulent financial reporting and company characteristics: tax audit evidence. Journal of Financial Reporting and Accounting 8 (2): 128-142.

Ntim, C. G., S. Lindop, and D. A. Thomas. 2013. Corporate governance and risk reporting in South Africa: A study of corporate risk disclosures in the pre- and post-2007/2008 global financial crisis periods. International Review of Financial Analysis 30: 363-383.

Oliveira, J., L. L. Rodrigues, and R. Craig. 2011a. Risk-related disclosure practices in the annual reports of Portuguese credit institutions: An exploratory study. Journal of Banking Regulation 12 (2): 100-118. 
Oliveira, J., L. L. Rodrigues, and R. Craig. 2011b. Risk-related disclosures by non-finance companies: Portuguese practices and disclosure characteristics. Managerial Auditing Journal 26 (9): 817-839.

Oliveira, J., L. L. Rodrigues, and R. Craig. 2013. Technical Note: Company Risk-related Disclosures in a Code Law Country: A Synopsis. Australasian Accounting Business and Finance Journal Article 7 (1): 123 130.

van Oorschot, L. 2009. Risk reporting: An analysis of the German banking industry. Master Thesis. Erasmus University Rotterdam.

Padia, N. 2012. Disclosure of non-financial information on strategy in South African annual reports. African Journal of Business Management 6(46): 11472-11479.

Probohudono, A. N., G. Tower, and R. Rusmin. 2013. Risk disclosure during the global financial crisis. Social Responsibility Journal 9 (1): 124-137.

Richardson, A., \& Welker, M. 2001. Social disclosure, financial disclosure and the cost of equity capital. Accounting, Organizations and Society 26 (7/8): 597-616.

Roberts, R. W. 1992. Determinants of corporate social responsibility disclosure: An application of stakeholder theory. Accounting, Organizations and Society 17 (6): 595-612.

Rogers, W. H. 1993. Regression standard errors in clustered samples. Stata Technical Bulletin 3: 88-94.

SEC. 1997. Disclosure of Accounting Policies for Derivative Financial Instruments and Derivative Commodity Instruments and Disclosure of Qualitative and Quantitative Information about Market Risk Inherent in Derivative Financial Instruments, other Financial Instruments, and Derivative Commodity Instruments. Washington: Securities and Exchange Commission.

Solomon, J. F., A. Solomon, S. D. Norton, and N. L. Joseph. 2000. A conceptual framework for corporate risk disclosure emerging from the agenda for corporate governance reform. The British Accounting Review 32 (4): 447-478.

Tabachnick, B. G., and L. S. Fidell. 2007. Using Multivariate Statistics. Boston: Allyn and Bacon.

Taylor, G., G. Tower, J. van D. Zahn, and J. Neilson. 2008. Corporate governance determinants on Australian resource companies' financial instrument disclosure practices. Asian Review of Accounting 16 (1): 56-73.

van Oorschot, L. 2009. Risk reporting: An analysis of the German banking industry. Master Thesis. Erasmus University Rotterdam.

Vandemaele, S., P. Vergauwen, and A. Michiels. 2009. Management risk reporting practices and their determinants. Woking Paper. Hasselt University, available at: http:// hdl.handle.net/1942/9392.

Wooldridge, J. M. 2002. Econometric Analysis of Cross Section and Panel Data. Cambridge, Massachusetts: MIT Press.

Zhang, X., D. Taylor, W. Qu, and J. Oliver. 2013. Corporate risk disclosures: influence of institutional shareholders and audit committee. Corporate Ownership and Control 10 (4): 341- 353. 


\section{Appendix A: Risk Disclosure Categories and Items}

\begin{tabular}{|c|c|}
\hline Categories & Items \\
\hline General Risk Information & $\begin{array}{l}\text { Strategic goals and plans } \\
\text { Prospects and Expectations } \\
\text { Political and Economic risks } \\
\text { Natural disasters } \\
\text { Competition in product market } \\
\text { New alliances and joint ventures }\end{array}$ \\
\hline Accounting Policies & $\begin{array}{l}\text { Use of estimates judgements } \\
\text { Collateral assets against loans } \\
\text { Financial assets impairment } \\
\text { Other assets impairment } \\
\text { De-recognition of financial assets } \\
\text { Risk management policies (general) } \\
\text { Objective of holding derivatives instruments } \\
\text { Contingent liabilities } \\
\text { Commitments capital expenditure } \\
\text { Contingent assets and gains } \\
\text { Inventory evaluation } \\
\text { Key sources of estimation uncertainty } \\
\text { Foreign currency translation }\end{array}$ \\
\hline Financial Instruments & $\begin{array}{l}\text { Reclassification of instruments } \\
\text { Cumulative change in fair value }\end{array}$ \\
\hline Derivatives Hedging & $\begin{array}{l}\text { Hedging description } \\
\text { Change in fair value of assets and liabilities } \\
\text { Cash flow hedge }\end{array}$ \\
\hline Segment Information & $\begin{array}{l}\text { Business major segments } \\
\text { Geographical major segments } \\
\text { Geographical concentration } \\
\text { Customers, suppliers, and assets' concentration }\end{array}$ \\
\hline Operational Risk & $\begin{array}{l}\text { Product and service developments } \\
\text { Product and service failures } \\
\text { Brand name erosion and change } \\
\text { Efficiency and performance } \\
\text { Performance incentives } \\
\text { Customer satisfaction } \\
\text { Internal control } \\
\text { Infrastructure } \\
\text { Information processing and technology risks } \\
\text { Recruiting of qualified and skilled professionals } \\
\text { Sourcing and availability } \\
\text { Continuity and sustainability } \\
\text { Health and safety } \\
\text { Environmental risk } \\
\text { Regulatory environment risk } \\
\text { Legal regulatory sanctions } \\
\text { Saudization risk } \\
\text { Reservations for chartered accountant } \\
\text { Events beyond balance sheet } \\
\text { Other operation risks }\end{array}$ \\
\hline
\end{tabular}




\section{Appendix A: Continued}

\begin{tabular}{ll}
\hline \multicolumn{1}{c}{ Categories } & \multicolumn{1}{c}{ Items } \\
\hline Financial Risk & Exposure to interest rate risk \\
& Managing interest rate risk \\
& Exposure to currency exchange rate risk \\
& Managing currency exchange rate risk \\
& Exposure to liquidity risk \\
& Managing liquidity risk \\
& Exposure to credit risk \\
& Managing credit risk \\
& Exposure to commodity price risk \\
& Managing commodity price risk \\
& Exposure to other price risk \\
& Sensitivity analysis \\
\hline
\end{tabular}

\section{Appendix B: Decision Rules for Corporate Risk Disclosures}

1. To identify risk disclosures, a broad definition of risk is to be adopted as explained below.

2. Sentences are to be coded as risk disclosures if the reader is informed of any opportunity or prospect, or of any hazard, danger, harm, threat or exposure, that has already impacted upon the company or may impact upon the company in the future, or of the management of any such opportunity, prospect, hazard, harm, threat or exposure.

3. The risk definition stated above shall be interpreted such that "good" or "bad" "risk" and uncertainties will be deemed to be contained within the definition.

4. Risk-related disclosures shall be classified according to risk disclosure categories and items in Appendix A.

5. If a sentence has more than one possible classification, the information will be classified into the category that is most emphasised within the sentences.

6. Tables (quantitative and qualitative) that provide risk information should be interpreted as one line equals one sentence and classified accordingly.

7. Any disclosure that is repeated shall be recorded as a risk disclosure sentence each time it is discussed.

8. If a disclosure is too vague in its reference to risk, then it shall not be recorded as risk disclosure.

Source: Linsley and Shrives (2006, p. 402) 
